\title{
Lymphocyte Subsets and the Role of Th1/Th2 Balance in Stressed Chronic Pain Patients
}

\author{
Ines Kaufmann Christoph Eisner Peter Richter Volker Huge Antje Beyer \\ Alexander Chouker Gustav Schelling Manfred Thiel \\ Department of Anesthesiology, Klinikum Grosshadern, Ludwig Maximilians University, Munich, Germany
}

\section{Key Words}

Chronic pain - Stress - Complex regional pain syndrome •

Fibromyalgia $\cdot$ Lymphocyte $\cdot$ Intracellular cytokine pain-induced neurohumoral stress response, and whether they contribute to immunosuppression in stressed chronic pain patients.

Copyright $\odot 2008$ S. Karger AG, Basel

\begin{abstract}
Background: The complex regional pain syndrome (CRPS) and fibromyalgia (FM) are chronic pain syndromes occurring in highly stressed individuals. Despite the known connection between the nervous system and immune cells, information on distribution of lymphocyte subsets under stress and pain conditions is limited. Methods: We performed a comparative study in 15 patients with CRPS type I, 22 patients with FM and 37 age- and sex-matched healthy controls and investigated the influence of pain and stress on lymphocyte number, subpopulations and the Th1/Th2 cytokine ratio in T lymphocytes. Results: Lymphocyte numbers did not differ between groups. Quantitative analyses of lymphocyte subpopulations showed a significant reduction of cytotoxic CD8+ lymphocytes in both CRPS $(p<0.01)$ and FM $(p<0.05)$ patients as compared with healthy controls. Additionally, CRPS patients were characterized by a lower percentage of IL-2-producing $T$ cell subpopulations reflecting a diminished Th1 response in contrast to no changes in the Th2 cytokine profile. Conclusions: Future studies are warranted to answer whether such immunological changes play a pathogenetic role in CRPS and FM or merely reflect the consequences of a
\end{abstract}

\section{Introduction}

Complex regional pain syndrome (CRPS) and fibromyalgia (FM) are chronic pain syndromes which are often preceded by extremely stressful experiences and other major adverse life events [1-7]. CRPS as well as FM have been classified as so-called central sensitization syndromes $[8,9]$ involving hyperexcitement of the central neurons through various synaptic activities and neurotransmitters leading to dysfunction of brain areas which regulate pain perception and stress responses.

Both disorders, however, differ in type and localization of pain. CRPS is a localized neuropathic pain syndrome usually occurring after a limb trauma without (type I) or with (type II) an injury of a peripheral nerve. Pain in CRPS patients is not proportionally related to the initial injury and does not follow a nerve innervation pattern. It is associated with autonomic dysregulation, swelling, motor and trophic signs [8]. FM is defined according to the classification criteria of the American College of Rheumatology which require the presence of self-report-

\section{KARGER}

Fax +4161306 1234 E-Mail karger@karger.ch www.karger.com
(C) 2008 S. Karger AG, Basel

1021-7401/07/0145-0272\$23.50/0

Accessible online at:

www.karger.com/nim
Manfred Thiel, MD, PhD

Department of Anesthesiology, Klinikum Grosshadern

Ludwig Maximilians University

DE-81377 Munich (Germany)

Tel. +49897095 6426, Fax +49 897095 8886, E-Mail mthiel@med.uni-muenchen.de 
Table 1. Baseline data of healthy volunteers and chronic pain patients (mean \pm SEM)

\begin{tabular}{lccc}
\hline & $\begin{array}{l}\text { Healthy } \\
\text { volunteers } \\
(\mathrm{n}=37)\end{array}$ & $\begin{array}{l}\text { CRPS } \\
\text { patients } \\
(\mathrm{n}=15)\end{array}$ & $\begin{array}{l}\text { FM } \\
\text { patients } \\
(\mathrm{n}=22)\end{array}$ \\
\hline $\begin{array}{l}\text { Age, years } \\
\begin{array}{l}\text { Gender (female/male) } \\
\text { Inflammation parameters }\end{array}\end{array}$ & $\begin{array}{c}52.2 \pm 2.1 \\
\quad 32 / 5\end{array}$ & $\begin{array}{c}53.9 \pm 4.1 \\
15 / 0\end{array}$ & $\begin{array}{c}53.1 \pm 2.1 \\
17 / 5\end{array}$ \\
$\quad$ Leukocytes, $10^{3}$ cells/ $\mu \mathrm{l}$ & $7.4 \pm 0.6$ & $7.1 \pm 0.5$ & $7.6 \pm 0.5$ \\
$\begin{array}{l}\text { Leukocyte subpopulations, \% } \\
\quad \text { Neutrophils }\end{array}$ & $59.2 \pm 1.2$ & $60.9 \pm 2.5$ & $60.6 \pm 1.9$ \\
$\quad \begin{array}{l}\text { Lymphocytes } \\
\text { Monocytes }\end{array}$ & $23.4 \pm 1.0$ & $20.7 \pm 1.8$ & $20.7 \pm 1.3$ \\
$\quad$ Eosinophils & $6.6 \pm 0.3$ & $5.9 \pm 0.3$ & $6.1 \pm 0.4$ \\
& $2.0 \pm 0.2$ & $3.0 \pm 0.5$ & $3.1 \pm 0.4$ \\
\hline
\end{tabular}

ed chronic widespread pain and 11 or more anatomically defined tender points upon palpation [10]. FM patients exhibit an exaggerated pain response upon digital pressure and are hypersensitive to heat, cold, electric stimuli as well as ischemia in many areas of the human body. Initial physical trauma may be involved in the pathogenesis of FM [9]; however, traumatic events are observed much less frequently than in CRPS.

Despite the known connection between the nervous system and immune cells [11-16], information on distribution of lymphocyte subsets under stress and pain conditions is limited [17]. In rodents, acute stress reduces CD4+ cells [18], and chronic social stress induces a decrease in CD4+ and CD8+ lymphocytes [19]. Acute human stress is known to increase CD8+ lymphocytes [2022] as well as to decrease CD4+ cells and the ratio of CD4+/CD8+ cells [23]. In contrast, in prolonged human stress responses such as posttraumatic stress disorder, lymphocyte subsets are not deranged [24]. With respect to chronic pain, information on alterations of lymphocyte subsets is inconsistent; cluster headache and low back pain lower the CD4+ subpopulation [25], while migraine is characterized by decreased levels of CD $8+\mathrm{T}$ lymphocytes [26].

T cells may be functionally defined by their cytokine profile. With regard to the CD4+ T helper (Th) cells, an adequate host immune response against infection is largely dependent on the activation of their two functionally distinct subsets, Th1 and Th2 cells $[12,13]$. The Th1/ Th2 balance is a prerequisite for the full functionality of immunity. Th 1 cells secrete more interferon- $\gamma$ and interleukin (IL)-2 and stimulate (cellular) type 1 immunity. Th1 responses promote production of opsonizing anti- bodies (e.g., IgG1) and induce cellular cytotoxicity by activation of macrophages with powerful phagocytic activity. Th2 lymphocytes produce more IL- 4 and IL-10 and induce humoral type 2 immunity with promotion of $\operatorname{IgE}$ and IgG4 production, thereby fine-tuning $B$ cell antibody production. Autoimmunity induces an imbalance between the Th1 and Th 2 response with a Th1 dominance. Trauma and cancer-bearing states are characterized by an increase in the Th2 cytokine production. To our knowledge, there are no studies in the literature examining Th1/Th2 balance in CRPS or FM, respectively.

Therefore, this study intended to test the hypothesis that lymphocyte subsets and, especially, percentages of $\mathrm{T}$ cell subsets producing proinflammatory and anti-inflammatory cytokines are different in CRPS and FM patients and related to the levels of self-perceived emotional stress.

\section{Materials and Methods}

The study was approved by the local ethics committee (protocol No. 324/02) and conducted in accordance with the guidelines of the declaration of Helsinki and its amendment in Tokyo, 1975, and Hong Kong, 1989. Data protection met the standards set by the German law.

Patients, Definitions and Entry Criteria

Fifteen CRPS type I patients classified according to the criteria of the International Association for the Study of Pain (IASP) [27] and Bruehl et al. [28] and 22 patients with FM defined according to the American College of Rheumatology [10] admitted to the Interdisciplinary Pain Clinic of the University Clinic of Munich, Germany were included in this study (table 1). FM patients had undergone a thorough evaluation by experienced rheumatologists in the setting of a university-affiliated center during which the diagnosis of FM was confirmed; other inflammatory or noninflammatory conditions mimicking FM were systematically excluded. Exclusion criteria were pregnancy, infection or other inflammation disorders, cancer, concurrent muscle or joint diseases, motor trauma or immunosuppressive medication (e.g., glucocorticoids). Patients with comorbid major depressive disorders or anxiety disorders were excluded. CRPS and FM patients abstained from intake of their current medication (tramadol, amitriptyline, diclofenac, ibuprofen, metamizole, $\gamma$-aminobutyric acid, or acetaminophen) for a period of $24 \mathrm{~h}$. Age- and sexmatched healthy subjects $(n=37)$ served as controls.

\section{Quantification of Pain and Stress Severity in CRPS and \\ FM Patients}

The mean pain score at the time of the assessment was determined by using a visual analogue scale with a range of $0-10$ (VAS). The intensity of emotional stress symptoms were measured using the German Version of the Post-traumatic Stress Symptom 10Questionnaire (PTSS-10). This instrument records the presence and intensity of 10 common stress symptoms: (1) sleep distur- 
Table 2. Severity of pain and stress (mean \pm SEM) in healthy subjects and chronic pain patients

\begin{tabular}{lllc}
\hline & $\begin{array}{l}\text { Healthy volun- } \\
\text { teers }(\mathrm{n}=37)\end{array}$ & $\begin{array}{l}\text { CRPS patients } \\
(\mathrm{n}=15)\end{array}$ & $\begin{array}{l}\text { FM patients } \\
(\mathrm{n}=22)\end{array}$ \\
\hline VAS & - & $4.0 \pm 0.9$ & $6.4 \pm 1.4$ \\
PTSS-10 & $21.3 \pm 7.0$ & $29.4 \pm 3.1^{*}$ & $46.7 \pm 3.5^{* *}$ \\
\hline
\end{tabular}

${ }^{*} \mathrm{p}<0.05 ;{ }^{* *} \mathrm{p}<0.0001$.

bance, (2) nightmares, (3) depression, (4) hyperalertness, (5) withdrawal (emotional numbing and inability to care for others), (6) generalized irritability, (7) frequent changes in mood, (8) guilt, (9) fear and avoidance reactions when reminded of hospitals and diseases and (10) increased muscle tension. Patients rate their symptoms, using a scale from 1 (never) to 7 (always) [29, 30].

\section{Biochemical Measurements}

Reagents. Fluorescence-activated cell sorting (FACS) permeabilizing solution, SimulTest IMK plus ${ }^{\circledR}$ kit, bovine serum albumin (BSA) and monoclonal antibodies [peridinin-chlorophyllprotein complex (PerCP)-conjugated anti-CD3, anti-CD4 and anti-CD8; fluorescein isothiocyanate (FITC)-conjugated antihuman IL-2 and anti-human interferon- $\gamma$; R-phycoerythrin (PE)conjugated anti-human-IL-4 and anti-human-IL-10] were obtained from Becton Dickinson (Heidelberg, Germany). Hanks' buffered salt solution (HBSS), phosphate-buffered saline (PBS) and $1 \%$ paraformaldehyde were manufactured from soluble ingredients by the hospital's own pharmacy. RPMI 1640, ionomycin and brefeldin A were purchased from Sigma-Aldrich (Taufkirchen, Germany).

Lymphocyte Populations. For immunophenotyping of lymphocyte populations a SimulTest IMK plus was used. Venous heparinized blood samples (heparin activity $10 \mathrm{IU} / \mathrm{ml}$ ) were incubated with each of six antibody reagents from the SimulTest IMK plus kit for $20 \mathrm{~min}$ at room temperature. Subsequently, the stained samples were treated with lysing solution to eliminate erythrocytes for $10 \mathrm{~min}$, washed with cold HBSS solution and put on ice until flow-cytometric analysis.

Intracellular Cytokine Synthesis. Heparinized blood (heparin activity $10 \mathrm{IU} / \mathrm{ml}$ ) was diluted with RPMI 1640 (ratio 1:1), and incubated for $4 \mathrm{~h}$ at $37^{\circ} \mathrm{C}, 7 \% \mathrm{CO}_{2}$, with $7.5 \mathrm{nmol} / 1$ phorbol myristate acetate and $1.34 \mathrm{nmol} / \mathrm{ml}$ ionomycin. After $1 \mathrm{~h}$ of incubation, $1.4 \mu \mathrm{mol} / \mathrm{l}$ brefeldin A was added. Subsequently, cells were incubated for $20 \mathrm{~min}$ at room temperature with PerCP-labeled monoclonal antibodies with specificity for surface antigens (CD3, CD4, CD8). Afterwards, erythrocytes were lysed with FACS lysing solution for $60 \mathrm{~min}$. After washing of cells with a buffer (PBS, BSA $0.5 \%, \mathrm{NaN}_{3} 0.1 \%$ ), they were permeabilized by incubation with permeabilizing solution for $10 \mathrm{~min}$ and stained with monoclonal antibodies against cytokines (FITC-marked: anti-interferon- $\gamma$, anti-IL-2; PE-marked: anti-IL-4, anti-IL-10). After a 2 -fold washing, cells were fixed with paraformaldehyde $1 \%$ and put on ice until analysis by flow cytometry as described below. However, for each sample in the assay an unstimulated and activated intracellular isotype staining control was run.
Control of Changes in Intracellular Cytokine Production for Changes in a Lymphocyte Subpopulation of Interest. Since an immunomodulating factor, like a stress hormone, might not only affect the capacity of a given lymphocyte subset to produce a regulatory cytokine, but also the blood concentration of the respective lymphocyte subset, we determined the ratio between the observed change in the cytokine-producing cells and the change of the lymphocyte subset. Specifically, we looked at whether a decrease in the IL-2-producing CD8+ cells was as strong as the reduction in the number of CD8+ lymphocytes.

Flow Cytometry. Samples were quantitatively analyzed by the use of a Becton Dickinson FACScan (Becton Dickinson, San Jose, Calif., USA) equipped with an argon laser emitting light at 488 $\mathrm{nm}$. During the study period, the instrument was intermittently calibrated and standardized by Calibrite beads (Becton Dickinson, Erembodegen-Aalst, Belgium).

Lymphocyte subpopulations were obtained following gating of lymphocytes on SSC/FSC dot plots and referred to the SimulSET Software User's Guide.

For intracellular cytokine analyses, a total of 10,000 events was collected. Lymphocytes were identified by means of their light SSC/FSC characteristics. The dual staining of samples allowed for discrimination of different $\mathrm{CD}$-positive lymphocyte $\mathrm{T}$ cell subpopulations (CD3, CD4, CD8) by live gating on the SSC/ FL3 dot plots followed by analyses of the percentage of cells producing IL- 2 and interferon- $\gamma$ and on the SSC/FL1 dot plots or IL4 and IL-10 on the SSC/FL2 dot plots (fig. 1). The specific response of cells was obtained by subtraction of the percentage of the isotype-corrected response of the unstimulated sample from the percentage of the isotype-corrected activated sample.

\section{Statistics}

Data analyses were performed with commercially available software (SPSS 13.0; SPSS, Chicago, Ill., USA). Normal distribution of data was tested by the Kolmogorov-Smirnov test. Comparisons between independent groups were performed by oneway ANOVA followed by a post hoc correction for multiple comparisons using the Bonferroni method. Correlations were analyzed using Pearson's correlation coefficient for normally distributed data. Data are considered to be significantly different at $\mathrm{p}<0.05$. Results are expressed as mean \pm SEM.

\section{Results}

\section{Baseline Characteristics}

There were no significant differences between healthy volunteers, CRPS and FM patients for baseline characteristics, leukocyte numbers and their subpopulations (table 1).

\section{Quantification of Disease Severity in Chronic Pain Patients}

Both CRPS and FM patients had evidence of severe chronic pain and stress as shown by scores on the VAS and the PTSS-10 instrument (table 2). PTSS-10 stress symptom scores in both CRPS and FM patients were 


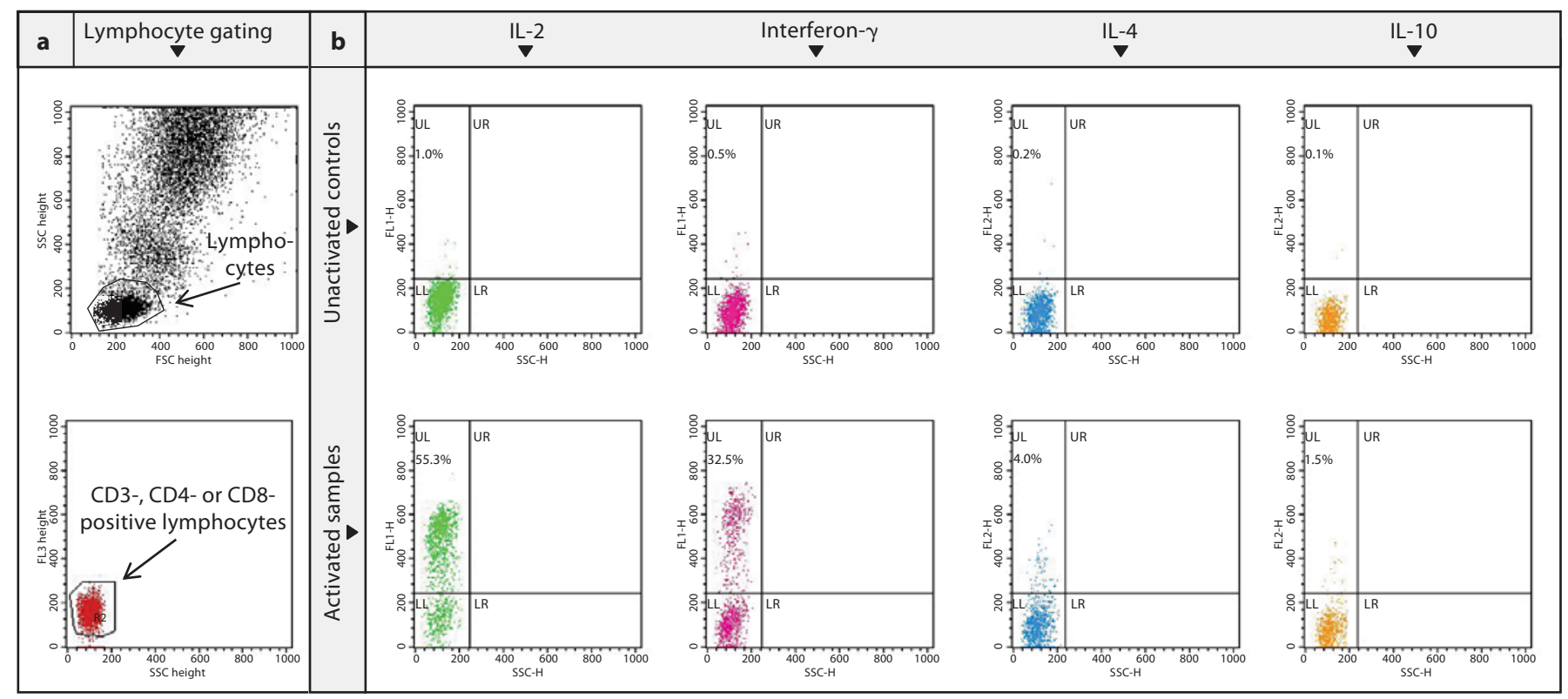

Fig. 1. a The FSC/SSC dot plot shows the gating of lymphocytes. The live gate in SSC/FL-3 dot plot identifies $\mathrm{CD} 3+, \mathrm{CD} 4+$ or CD8+ lymphocytes depending on the PerCP-labeled surface antibody used (anti-CD3, antiCD4, anti-CD8). b Dot plots show IL-2-, interferon- $\gamma$-, IL-4- and IL-10-positive T lymphocyte subpopulations (as immunophenotyped by the respective cell surface marker gated in a (CD3+, CD4+ or CD8+ cells). Comparison was made between cells in a resting state or after activation by a combination of phorbol myristate acetate $(7.5 \mathrm{nmol} / \mathrm{l})$ and ionomycin $(1.34 \mathrm{nmol} / \mathrm{ml})$.

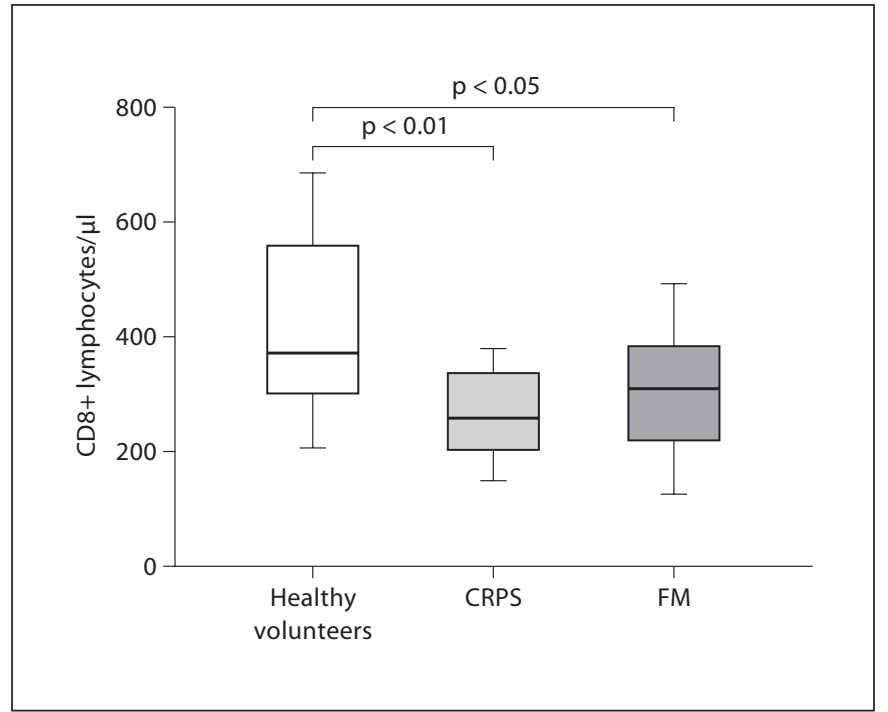

Fig. 2. Plots of the absolute numbers of CD8+ lymphocytes per microliter in healthy volunteers $(\mathrm{n}=37)$, patients with CRPS $(\mathrm{n}=$ $15)$ and FM $(n=22)$. The top of the box represents the 75 th percentile and the bottom the 25 th percentile. The horizontal line in the box represents the median value, and the lines above and below the box are whiskers to the 95th and 5th percentiles, respectively. massively increased and significantly higher than values for healthy individuals (CRPS: $\mathrm{p}<0.05$; FM: $\mathrm{p}<$ 0.0001).

\section{Lymphocyte Subpopulations}

The number of cytotoxic T cells (CD8+) was significantly diminished in patients with CRPS $(\mathrm{p}<0.01)$ and FM $(\mathrm{p}<0.05)$ as compared with healthy volunteers (fig. 2). However, the CD4/CD8 ratio increased only in CRPS patients to a significant extent (healthy volunteers: $2.2 \pm 0.1$; CRPS patients: $2.8 \pm 0.2 ; \mathrm{p}<0.01$ ).

The proportion of CD8+ subset correlated negatively with the PTSS-10 score in FM patients $(\mathrm{r}=-0.55 ; \mathrm{p}<0.05$; fig. 3), but not in CRPS patients. No correlation was found for CD8+ subsets and VAS scores in both CRPS and FM.

With regard to the numbers of $\mathrm{B}$ cells (CD19+), T cells (CD3+), helper T cells (CD4+), natural killer cell population (CD3-CD16+CD56+) and CD3+CD16+CD56+lymphocytes, no differences were observed between chronic pain patients and healthy volunteers, respectively (data not shown). 


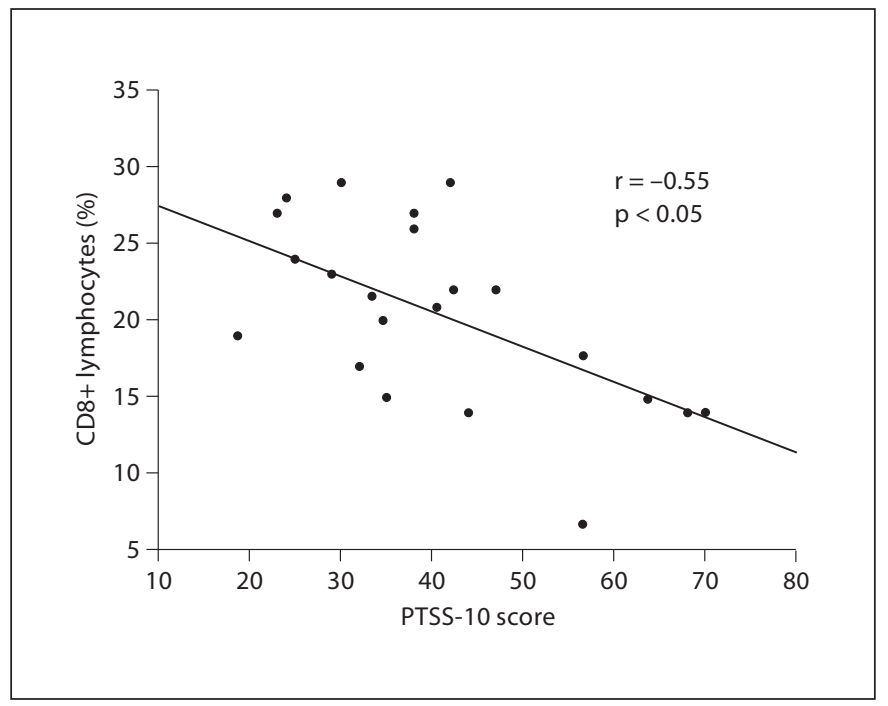

Fig. 3. Correlation between PTSS-10 scores and the proportion of CD8+ lymphocytes in FM patients. Using Pearson's correlation, the correlation coefficient, Pearson's r, also called linear or product-moment correlation, was determined.

\section{Intracellular Cytokine Production}

With regard to the percentages of IL-2-producing CD3+, CD4+ and CD8+ lymphocytes (fig. 4), lower values were obtained in CRPS patients $(\mathrm{CD} 3+, \mathrm{p}<0.05$; $\mathrm{CD} 4+, \mathrm{p}<0.05 ; \mathrm{CD} 8+, \mathrm{p}<0.01$ ), but not in FM patients $(\mathrm{CD} 3+, \mathrm{p}=0.13 ; \mathrm{CD} 4+, \mathrm{p}=0.36 ; \mathrm{CD} 8+, \mathrm{p}=0.12)$. When the decrease in IL-2-producing CD8+ cells was controlled for the decrease in the CD8+ cells, the decline of IL-2 positive cells was 1.6-fold stronger than that of $\mathrm{CD} 8+$ cells.

When compared to healthy volunteers, no significant differences were observed for percentages of $\mathrm{CD} 3+$, CD4+ and CD8+ lymphocytes of CRPS and FM patients producing proinflammatory interferon- $\gamma$. However, CRPS patients showed enhanced anti-inflammatory IL4 and immunoregulatory IL-10 production (IL-4: CD3+, $\mathrm{p}=0.45 ; \mathrm{CD} 4+, \mathrm{p}=0.37 ; \mathrm{CD} 8+, \mathrm{p}=0.45 ; \mathrm{IL}-10: \mathrm{CD} 3+$, $\mathrm{p}=0.05 ; \mathrm{CD} 4+, \mathrm{p}=0.17 ; \mathrm{CD} 8+, \mathrm{p}=0.47)$ without reaching significance (table 3 ). Similarly, FM patients were also characterized by a tendency of increased IL-4 $(\mathrm{CD} 3+, \mathrm{p}=0.05 ; \mathrm{CD} 4+, \mathrm{p}=0.05 ; \mathrm{CD} 8+, \mathrm{p}=0.12)$ and IL-10 production $(\mathrm{CD} 3+, \mathrm{p}=0.06 ; \mathrm{CD} 4+, \mathrm{p}=0.45 ; \mathrm{CD} 8+$, $\mathrm{p}=0.97)$.

The Th1/Th2 ratios calculated on the basis of the percentages or the absolute number of Th cells producing cytokines were significantly different between healthy volunteers and CRPS patients (both $\mathrm{p}<0.05$ ).

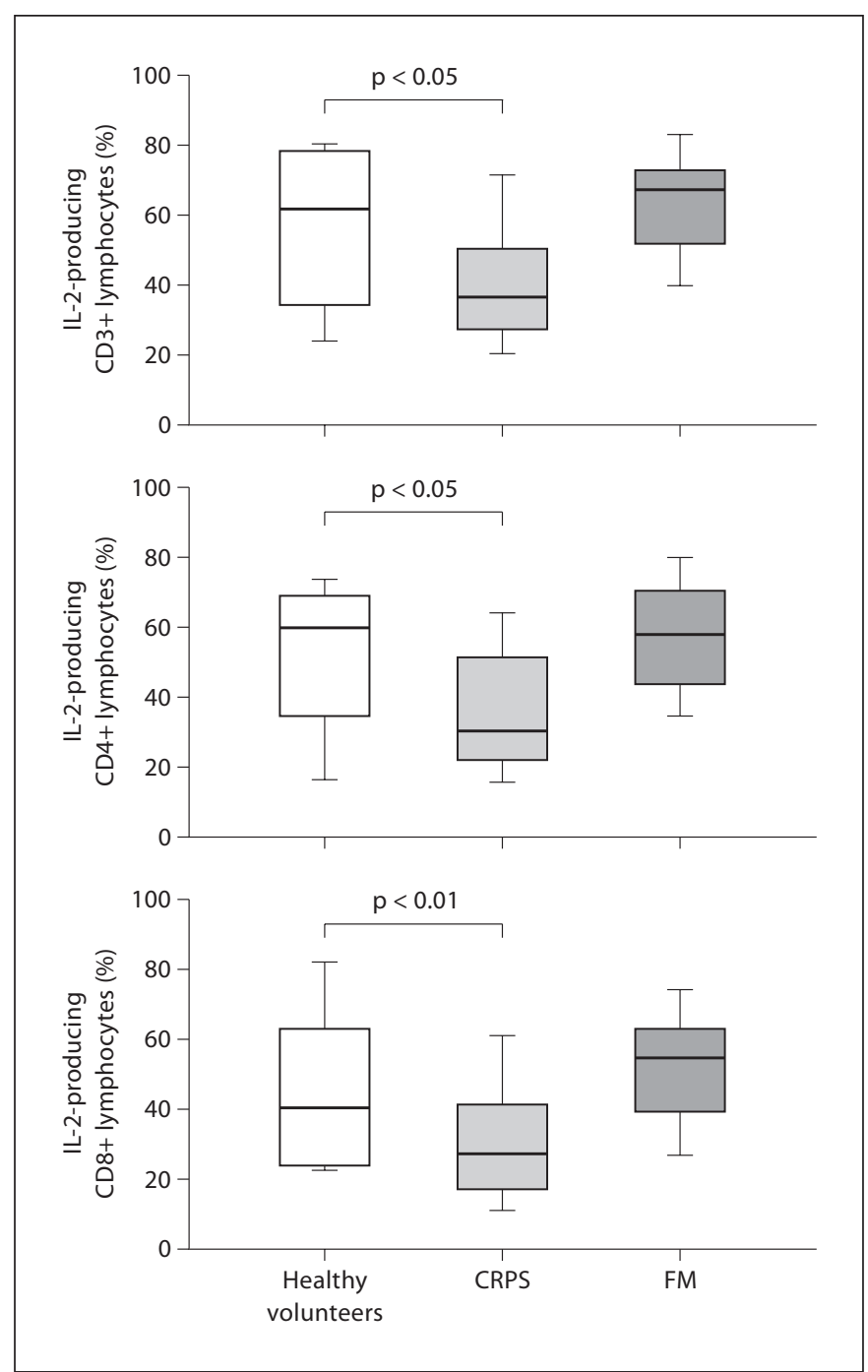

Fig. 4. Plots of the percentages of IL-2-producing T lymphocytes (CD3+), Th cells (CD4+) and cytotoxic T cells (CD8+) in healthy volunteers $(n=37)$, patients with CRPS $(n=15)$ and FM $(n=22)$. The top of the box represents the 75th percentile and the bottom the 25th percentile. The horizontal line in the box represents the median value, and the lines above and below the box are whiskers to the 95 th and 5 th percentiles, respectively.

\section{Discussion}

This study compared lymphocyte numbers, subpopulations and their intracellular cytokine production in patients with CRPS, FM and healthy controls. CRPS and FM patients were selected because these patients suffer from chronic pain syndromes accompanied by a high degree of emotional stress. Major findings of this study are: (1) total lymphocyte numbers did not differ between 
Table 3. Intracellular cytokine production by $\mathrm{T}$ lymphocyte subpopulations (mean $\pm \mathrm{SEM}$ )

\begin{tabular}{|c|c|c|c|}
\hline & $\begin{array}{l}\text { Healthy volun- } \\
\text { teers }(\mathrm{n}=37)\end{array}$ & $\begin{array}{l}\text { CRPS patients } \\
(\mathrm{n}=15)\end{array}$ & $\begin{array}{l}\text { FM patients } \\
(\mathrm{n}=22)\end{array}$ \\
\hline \multicolumn{4}{|c|}{ Interferon- $\gamma$-producing lymphocytes, $\%$} \\
\hline $\mathrm{CD} 3+$ & $32.1 \pm 3.3$ & $34.8 \pm 3.5$ & $37.7 \pm 2.7$ \\
\hline CD4+ & $27.4 \pm 5.5$ & $33.3 \pm 4.7$ & $35.0 \pm 3.8$ \\
\hline CD8+ & $52.0 \pm 4.8$ & $52.8 \pm 3.7$ & $62.6 \pm 3.9$ \\
\hline \multicolumn{4}{|c|}{ IL-4-producing lymphocytes, \% } \\
\hline $\mathrm{CD} 3+$ & $3.2 \pm 0.5$ & $3.8 \pm 0.5$ & $5.2 \pm 0.5$ \\
\hline CD4+ & $2.8 \pm 0.9$ & $3.8 \pm 0.8$ & $4.8 \pm 0.7$ \\
\hline CD8+ & $6.5 \pm 1.3$ & $5.3 \pm 1.1$ & $6.8 \pm 1.0$ \\
\hline \multicolumn{4}{|c|}{ IL-10-producing lymphocytes, $\%$} \\
\hline $\mathrm{CD} 3+$ & $1.4 \pm 0.2$ & $2.3 \pm 0.3$ & $1.9 \pm 0.2$ \\
\hline CD4+ & $1.0 \pm 0.2$ & $2.4 \pm 0.7$ & $1.6 \pm 0.9$ \\
\hline CD8+ & $2.5 \pm 0.4$ & $2.9 \pm 0.3$ & $2.5 \pm 1.5$ \\
\hline
\end{tabular}

healthy volunteers and both groups of stressed chronic pain patients, (2) quantitative analyses of lymphocyte subpopulations showed a clear reduction of the cytotoxic CD8+ lymphocytes in both CRPS and FM patients as compared with healthy controls, and (3) CRPS patients were characterized by a lowered percentage of IL-2-producing $\mathrm{CD} 3+/ \mathrm{CD} 4+/ \mathrm{CD} 8+\mathrm{T}$ cells reflecting a diminished Th1 response in contrast to no changes in the Th2 cytokine profile, an effect which was not seen in FM patients.

\section{Decrease in the CD8+Lymphocyte Subpopulation in} Chronic Pain

Only a few trials on immunity in chronic stress and pain have been published to date and even fewer addressed CRPS and FM. It is known that lymphocytes show an altered subset distribution under conditions of stress and pain $[21-23,25,26]$. We noticed significantly decreased numbers of cytotoxic CD8+ lymphocytes in both chronic pain patient groups as it has been described for chronic tension-type headache [31] and migraine sufferers [26, 31]. However, our study did not confirm either changes in lymphocyte counts or percentages of CD3+ and CD4+ cells $[23,25]$ in stressed pain patients.

Cytotoxic CD8+ T cells play an important role in the recognition and destruction of cells expressing foreign antigens, e.g. of viral or tumor origin $[32,33]$. It is known that pediatric patients with a persistent lack in CD8+ T cells develop numerous infections attributable to bacteria and fungi [34]. However, further studies are needed to determine whether a diminished number of CD8+ T cells leads to increased susceptibility of chronic pain patients towards infections and tumor development.

The decrease in CD8+ lymphocytes is known to result in part from chronic stress $[19,35]$ mediated through the activation of the sympathetic nervous system. This is corroborated by our finding of a negative correlation between PTSD scores and CD8+ T cell proportion in FM patients. The absence of a correlation in CRPS patients is probably due to the smaller sample size. Furthermore, it should be taken into consideration that PTSS-10 scores in CRPS patients show a small range of variation making detection of statistically significant correlations difficult. Interestingly, pain magnitude did not influence CD8+ subsets suggesting that pain alone is not the all-dominant factor in CD8+ cell decrease.

\section{Decreased Intracellular IL-2 Production by T Lymphocytes in Contrast to an Unchanged Th2 Cytokine Profile in CRPS}

Besides cytotoxic CD8+ T cells, the other and most important fraction of CD3+ T lymphocytes is represented by CD4+ Th cells. Naive CD4+ Th cells (Th0) can differentiate into functionally distinct subsets, Th1 and Th2 cells. Th1 cells secrete more interferon- $\gamma$ and IL-2 and stimulate type 1 immunity participating in cellular immune responses against intracellular pathogens like viruses and some bacteria. Th2 cells produce more IL-4 and IL-10 and induce humoral type 2 immunity $[12,13]$. In our study, CRPS patients were characterized by a significant decrease in IL-2-producing percentages of CD3+ T lymphocytes, CD4+ Th cells and CD8+ cytotoxic T cells (fig. 4). Based on these findings one might conclude a reduced $\mathrm{Th} 1$ response.

The impaired capacity of CD8+ cells to produce IL-2, however, cannot fully be explained by a decrease in the absolute number of circulating CD8+ cells because the decrease in IL-2-positive cells was much more pronounced than the reduction in the CD8+ lymphocyte blood count. As the decrease in IL-2 production in CD8+ cells was over-proportional to the decline in CD8+ cell counts, one might suggest these changes to be independent phenomena. In this regard it is interesting to note that also CD4+ T lymphocyte exhibited significantly less IL-2 production in CRPS patients, irrespective of the number of CD4+ cells in blood. This might be in further support of a factor or factors able to selectively decrease IL-2 production without suppressing the number of circulating CD4+ lymphocytes.

In contrast, no significant changes were observed for IL-2-producing $\mathrm{T}$ cells of FM patients. Both patient 
groups showed a slight, nonsignificant increase in their anti-inflammatory IL- 4 and IL-10 production suggesting a minimally enhanced Th2 response. The Th1/Th2 ratio was significantly decreased in CRPS patients only.

Although polarization of the immune response has been documented in many other clinical conditions [3641], the exact cause for a Th1/Th2 imbalance - as observed in our CRPS patients - still remains unknown.

Stress may influence the differentiation of bipotential Th cells away from a Th1 phenotype toward a Th2 phenotype. Early studies in animals revealed that sympathetic stimulation is able to inhibit Th1 responses via $\beta$ adrenergic receptor stimulation [42, 43]. It is known that sympathetic activation of the human nervous system is associated with the release of catecholamines and an enhanced Th2 cytokine production [44]. Both CRPS [45] and FM [46] patients were shown to exhibit increased noradrenaline levels. However, it is difficult to explain why the Th1/Th2 imbalance only occurs in CRPS patients and not in FM subjects. It could be that, conversely, predominance of a Th2-mediated immune response may induce antigen-specific B lymphocytes to produce specific antibodies which promote a secondary enhancement of the Th1 response leading to an autoimmune clinical picture, respectively [47]. This hypothesis is supported by an increased frequency of thyroid antibodies in FM [48]. The form of Th1/Th2 imbalance due to catecholamine release could be blocked by $\beta$-adrenoceptor antagonists [49] which might be a therapeutic alternative in some of the CRPS patients.

Second, a reduced Th1 response could be elicited by a strong Th2 response induced by low affinity interactions of $\mathrm{T}$ cell receptors with relatively low doses of antigen or peptide ligands [50]. In CRPS patients, this syndrome might develop after limb injury as a result of increased (neuron-)peptide levels [51] and additional infections [52]. In FM, trauma or infections occur much less frequently than in CRPS [53]; thus, associated peptide or antigen ligands as a cause for Th2 polarization are rarely possible.

As a third mechanism, glucocorticoids might act directly or indirectly via a decrease in IL-12 or IFN- $\gamma$ production, thereby attenuating a Th1 response. In this way, an elevation of plasma cortisol could induce a decrease in the Th1 products resulting in an imbalance between Th1/ Th2 cytokines [54]. However, no changes of plasma cortisol could be detected in CRPS [52]. Furthermore, in contrast, glucocorticoids are considered as a therapeutic option in early CRPS [55].

In addition, altered dehydroepiandrosterone (DHEA) levels which occur under acute and chronic inflamma- tory conditions $[56,57]$ may also exert some influence on Th1 and Th2 cytokines. In vitro DHEA was able to decrease Th1 and increase Th2 cytokine production [58]. The role of DHEA in chronic pain patients is still not characterized and represents an emerging field of investigations.

\section{Study Limitations}

Our study has several limitations. A possible confounding factor in our study is the concurrent use of analgetic and antidepressive medication. A prolonged washout period of all analgetic and antidepressive medication in chronic pain patients is difficult to be completely achieved and may be ethically unacceptable. However, patients abstained from intake of drugs for a period of $24 \mathrm{~h}$. A direct interaction between the use of opioids and immunological mechanisms cannot be definitely excluded [59]. Despite an in vitro induction of apoptosis by tricyclic antidepressants [60], clinically used amitryptiline is not known to influence leukocyte functions. The halflife of the other drugs ranging between 1.5 and $6 \mathrm{~h}$ is in our opinion too short to affect lymphocyte function because the time interval between the intake of the last dosage and blood withdrawal was longer than $24 \mathrm{~h}$.

Finally, a comparison between intracellular and secreted cytokines, a more detailed analysis of lymphocyte subpopulations such as regulatory $\mathrm{T}$ cells, functional assays of such lymphocyte subpopulations and determination of hormone secretion are lacking in our study.

\section{Conclusion}

CRPS and FM patients show decreased numbers of CD8+ cells probably due to a stress-associated activation of the sympathetic nervous system. CRPS patients are characterized by a diminished Th1 response, as suggested by an attenuated intracellular IL-2 production. Future studies are warranted to answer whether such immunological changes play a pathogenetic role in CRPS and FM or merely reflect the consequences of a pain-induced neurohumoral stress response.

\section{Acknowledgments}

The authors gratefully acknowledge the skilful technical assistance of Marion Hörl, Gaby Gröger and Stefan Meindl from the Department of Anesthesiology. 


\section{References}

1 Geertzen JH, Bruijn-Kofman AT, de Bruijn HP, van de Wiel HB, Dijkstra PU: Stressful life events and psychological dysfunction in complex regional pain syndrome type I. Clin J Pain 1998;14:143-147.

2 Grande LA, Loeser JD, Ozuna J, Ashleigh A, Samii A: Complex regional pain syndrome as a stress response. Pain 2004;110:495498.

3 Hudson JI, Arnold LM, Keck PE Jr, Auchenbach MB, Pope HG: Family study of fibromyalgia and affective spectrum disorder. Biol Psychiatry 2004;56:884-891.

4 McEwen BS: Physiology and neurobiology of stress and adaptation: central role of the brain. Physiol Rev 2007;87:873-904.

5 Van Houdenhove B, Egle U, Luyten P: The role of life stress in fibromyalgia. Curr Rheumatol Rep 2005;7:365-370.

6 Van Houdenhove B, Luyten P: Stress, depression and fibromyalgia. Acta Neurol Belg 2006;106:149-156.

7 Walker EA, Keegan D, Gardner G, Sullivan M, Bernstein D, Katon WJ: Psychosocial factors in fibromyalgia compared with rheumatoid arthritis. 2. Sexual, physical, and emotional abuse and neglect. Psychosom Med 1997;59:572-577.

8 Schwartzman RJ, Alexander GM, Grothusen J: Pathophysiology of complex regional pain syndrome. Expert Rev Neurother 2006;6: 669-681.

9 Yunus MB: Fibromyalgia and overlapping disorders: the unifying concept of central sensitivity syndromes. Semin Arthritis Rheum 2007;36:339-356.

10 Wolfe F, Smythe HA, Yunus MB, Bennett RM, Bombardier C, Goldenberg DL, Tugwell P, Campbell SM, Abeles M, Clark P, Fam AG, Farber SJ, Fiechtner JJ, Franklin CM, Gatter RA, Hamaty D, Lessard J, Lichtbroun AS, Masi AT, McCain GA, Reynolds WJ, Romano TJ, Russell IJ, Sheon RP: The American College of Rheumatology 1990 Criteria for the Classification of Fibromyalgia. Report of the Multicenter Criteria Committee. Arthritis Rheum 1990;33:160-172.

11 Brogden KA, Guthmiller JM, Salzet M, Zasloff $\mathrm{M}$ : The nervous system and innate immunity: the neuropeptide connection. Nat Immunol 2005;6:558-564.

12 Elenkov IJ, Wilder RL, Chrousos GP, Vizi ES: The sympathetic nerve - an integrative interface between two supersystems: the brain and the immune system. Pharmacol Rev 2000;52:595-638.

13 Elenkov IJ, Iezzoni DG, Daly A, Harris AG, Chrousos GP: Cytokine dysregulation, inflammation and well-being. Neuroimmunomodulation 2005; 12:255-269.

14 Herbert TB, Cohen S: Stress and immunity in humans: a meta-analytic review. Psychosom Med 1993;55:364-379.
15 Joachim RA, Sagach V, Quarcoo D, Dinh T, Arck PC, Klapp BF: Upregulation of tumor necrosis factor-alpha by stress and substance $\mathrm{P}$ in a murine model of allergic airway inflammation. Neuroimmunomodulation 2006; 13:43-50.

16 Kaufmann I, Eisner C, Richter P, Huge V, Beyer A, Chouker A, Schelling G, Thiel M: Psychoneuroendocrine stress response may impair neutrophil function in complex regional pain syndrome. Clin Immunol 2007; 125:103-111.

17 Marchand F, Perretti M, McMahon SB: Role of the immune system in chronic pain. Nat Rev Neurosci 2005;6:521-532.

18 Tarcic N, Levitan G, Ben Yosef D, Prous D, Ovadia H, Weiss DW: Restraint stress-induced changes in lymphocyte subsets and the expression of adhesion molecules. Neuroimmunomodulation 1995;2:249-257.

19 Stefanski V, Engler H: Social stress, dominance and blood cellular immunity. J Neuroimmunol 1999;94:144-152.

20 Buske-Kirschbaum A, Kern S, Ebrecht M, Hellhammer DH: Altered distribution of leukocyte subsets and cytokine production in response to acute psychosocial stress in patients with psoriasis vulgaris. Brain Behav Immun 2007;21:92-99.

21 Hennig J, Netter P, Voigt KH: Cortisol mediates redistribution of CD8+ but not of CD56+ cells after the psychological stress of public speaking. Psychoneuroendocrinology 2001; 26:673-687.

22 Sgoutas-Emch SA, Cacioppo JT, Uchino BN, Malarkey W, Pearl D, Kiecolt-Glaser JK, Glaser R: The effects of an acute psychological stressor on cardiovascular, endocrine, and cellular immune response: a prospective study of individuals high and low in heart rate reactivity. Psychophysiology 1994;31: 264-271.

23 Caggiula AR, McAllister CG, Matthews KA Berga SL, Owens JF, Miller AL: Psychological stress and immunological responsiveness in normally cycling, follicular-stage women. J Neuroimmunol 1995;59:103-111.

24 Vidovic A, Vilibic M, Sabioncello A, Gotovac K, Rabatic S, Folnegovic-Smalc V, Dekaris D: Circulating lymphocyte subsets, natural killer cell cytotoxicity, and components of hypothalamic-pituitary-adrenal axis in Croatian war veterans with posttraumatic stress disorder: cross-sectional study. Croat Med J 2007;48:198-206.

25 Bussone G, Salmaggi A, Leone M, Valentini S, Dufour A, Nespolo A: Immunological alterations in cluster headache during remission and cluster period. Comparison with low back pain patients. Cephalalgia 1992;12: 250-253.
26 Leone M, Biffi M, Leoni F, Bussone G: Leukocyte subsets and cortisol serum levels in patients with migraine without aura and chronic tension-type headache. Cephalalgia 1994;14:139-142.

27 Stanton-Hicks M, Jänig W, Hassenbusch S, Haddox JD, Boas R, Wilson P: Reflex sympathetic dystrophy - changing concepts and taxonomy. Pain 1995;63:127-133.

28 Bruehl S, Harden RN, Galer BS, Saltz S, Bertram M, Backonja M, Gayles R, Rudin N, Bhugra MK, Stanton-Hicks M: External validation of IASP diagnostic criteria for complex regional pain syndrome and proposed research diagnostic criteria. Pain 1999;81: 147-154.

29 Stoll C, Kapfhammer HP, Rothenhausler HB, Haller M, Briegel J, Schmidt M, Krauseneck T, Durst K, Schelling G: Sensitivity and specificity of a screening test to document traumatic experiences and to diagnose posttraumatic stress disorder in ARDS patients after intensive care treatment. Intensive Care Med 1999;25:697-704

30 Weisaeth L: Torture of a Norwegian ship's crew. The torture, stress reactions and psychiatric after-effects. Acta Psychiatr Scand Suppl 1989;355:63-72.

31 Gilman-Sachs A, Robbins L, Baum L: Flow cytometric analysis of lymphocyte subsets in peripheral blood of chronic headache patients. Headache 1989;29:290-294.

32 Milosevic DB: The different level of immunological recovery after chemotherapy in leukemia and lymphoma patients. J Exp Clin Cancer Res 2001;20:517-522.

33 Smyth LJ, Elkord E, Taher TE, Jiang HR, Burt DJ, Clayton A, van Veelen PA, de Ru A, Ossendorp F, Melief CJ, Drijfhout JW, Dermime S, Hawkins RE, Stern PL: CD8 T-cell recognition of human $5 \mathrm{~T} 4$ oncofetal antigen. Int J Cancer 2006;119:1638-1647.

34 Reichenbach J, Schubert R, Horvath R, Petersen J, Futterer N, Malle E, Stumpf A, Gebhardt BR, Koehl U, Schraven B, Zielen S: Fatal neonatal-onset mitochondrial respiratory chain disease with $\mathrm{T}$ cell immunodeficiency. Pediatr Res 2006;60:321-326.

35 Kubera M, Basta-Kaim A, Holan V, Simbirtsev A, Roman A, Pigareva N, Prokopieva E, Sham J: Effect of mild chronic stress, as a model of depression, on the immunoreactivity of C57BL/6 mice. Int J Immunopharmacol 1998;20:781-789.

36 Avgustin B, Wraber B, Tavcar R: Increased Th-1 and Th-2 immune reactivity with relative $\mathrm{Th}-2$ dominance in patients with acute exacerbation of schizophrenia. Croat Med J 2005;46:268-274

37 Liblau RS, Singer SM, McDevitt HO: Th1 and Th2 Cd4(+) T cells in the pathogenesis of organ-specific autoimmune diseases. Immunol Today 1995;16:34-38. 
38 Radstake TRDJ, van Lent PLEM, Pesman GJ, Blom AB, Sweep FGJ, Ronnelid J, Adema GJ, Barrera P, van den Berg WB: High production of proinflammatory and Th1 cytokines by dendritic cells from patients with rheumatoid arthritis, and down regulation upon Fc gamma $\mathrm{R}$ triggering. Ann Rheum Dis 2004;63:696-702.

39 Smart JM, Suphioglu C, Kemp AS: Age-related $\mathrm{T}$ cell responses to allergens in childhood. Clin Exp Allergy 2003;33:317-324.

40 Tournoy KG, Kips JC, Pauwels RA: The allergen-induced airway hyperresponsiveness in a human-mouse chimera model of asthma is T cell and IL-4 and IL-5 dependent. J Immunol 2001;166:6982-6991.

41 Tournoy KG, Kips JC, Pauwels RA: Counterbalancing of $\mathrm{T}(\mathrm{H}) 2$-driven allergic airway inflammation by IL-12 does not require IL10. J Allergy Clin Immunol 2001;107:483491.

42 Sanders VM, Baker RA, Ramer-Quinn DS, Kasprowicz DJ, Fuchs BA, Street NE: Differential expression of the beta(2)-adrenergic receptor by Th1 and Th2 clones - implications for cytokine production and B cell help. J Immunol 1997;158:4200-4210.

43 Woiciechowsky C, Asadullah K, Nestler D, Eberhardt B, Platzer C, Schoning B, Glockner F, Lanksch WR, Volk HD, Docke WD: Sympathetic activation triggers systemic interleukin-10 release in immunodepression induced by brain injury. Nat Med 1998;4: 808-813.

44 Woiciechowsky C, Volk HD: Increased intracranial pressure induces a rapid systemic interleukin-10 release through activation of the sympathetic nervous system. Acta Neurochir Suppl 2005;95:373-376.
45 Harden RN, Rudin NJ, Bruehl S, Kee W, Parikh DK, Kooch J, Duc T, Gracely RH: Increased systemic catecholamines in complex regional pain syndrome and relationship to psychological factors: a pilot study. Anesth Analg 2004;99:1478-1485.

46 Hamaty D, Valentine JL, Howard R, Howard CW, Wakefield V, Patten MS: The plasma endorphin, prostaglandin and catecholamine profile of patients with fibrositis treated with cyclobenzaprine and placebo: a 5-month study. J Rheumatol Suppl 1989;19:164-168.

47 Tsatsoulis A: The role of stress in the clinical expression of thyroid autoimmunity. Ann NY Acad Sci 2006;1088:382-395.

48 Pamuk ON, Cakir N: The frequency of thyroid antibodies in fibromyalgia patients and their relationship with symptoms. Clin Rheumatol 2007;26:55-59.

49 Gage JR, Fonarow G, Hamilton M, Widawski M, Martinez-Maza O, Vredevoe DL: Beta blocker and angiotensin-converting enzyme inhibitor therapy is associated with decreased Th1/Th2 cytokine ratios and inflammatory cytokine production in patients with chronic heart failure. Neuroimmunomodulation 2004;11:173-180.

50 Constant SL, Bottomly K: Induction of Th1 and Th2 CD4+ T cell responses: the alternative approaches. Annu Rev Immunol 1997; 15:297-322.

51 Schinkel C, Gaertner A, Zaspel J, Zedler S, Faist E, Schuermann M: Inflammatory mediators are altered in the acute phase of posttraumatic complex regional pain syndrome. Clin J Pain 2006;22:235-239.

52 Van de Vusse AC, Goossens VJ, Kemler MA, Weber WEJ: Screening of patients with complex regional pain syndrome for antecedent infections. Clin J Pain 2001;17:110-114.
53 Sarzi-Puttini P, Atzeni F, Diana A, Doria A, Furlan R: Increased neural sympathetic activation in fibromyalgia syndrome. Ann NY Acad Sci 2006;1069:109-117.

54 Li M, Wang Y, Guo R, Bai Y, Yu Z: Glucocorticoids impair microglia ability to induce $\mathrm{T}$ cell proliferation and Th1 polarization. Immunol Lett 2007;109:129-137.

55 Okada M, Suzuki K, Hidaka T, Shinohara T, Kataharada K, Takada K, Tanaka H, Ohsuzu F: Complex regional pain syndrome type I induced by pacemaker implantation, with a good response to steroids and neurotropin. Intern Med 2002;41:498-501.

56 Marx C, Petros S, Bornstein SR, Wiese M, Wendt M, Menschikowski M, Engelmann L, Höffken G: Adrenocortical hormones in survivors and nonsurvivors of severe sepsis: diverse time course of dehydroepiandrosterone, dehydroepiandrosterone-sulfate and cortisol. Crit Care Med 2003;31:1382-1388.

57 Maggio M, Ceda GP, Denti L, Rebecchi I, Manganelli P, Ablondi F, Valenti G: Decreased DHEAS secretion in patients with chronic inflammatory diseases treated with glucocorticoids. J Endocrinol Invest 2002; 25(10 suppl):87-88.

58 Powell JM, Sonnenfeld G: The effects of dehydroepiandrosterone (DHEA) on in vitro spleen cell proliferation and cytokine production. J Interferon Cytokine Res 2006;26: 34-39.

59 Sacerdote P: Opiods and the immune system. Palliat Med 2006;20(suppl 1):S9-S15

60 Karlsson H, Gu Y, DePierre J, Nässberger L: Induction of apoptosis in proliferating lymphocytes by tricyclic antidepressants. Apoptosis 1998;3:255-260. 